\title{
THIRTY-SIXTH ANNUAL LIST OF PAPERS
}

READ BEFORE THE AMERICAN MATHEMATICAL SOCIETY AND SUBSEQUENTLY PUBLISHED, INCLUDING REFERENCES TO THE PLACES OF PUBLICATION

Ayres, W. L. A new characterization of plane continuous curves. Read Oct. 30, 1926. This Bulletin, vol. 33, No. 2, pp. 201-208; March-April, 1927.

Concerning continuous curves and correspondences. Read Oct. 31, 1925, Jan. 2, 1926, and May 1, 1926. Annals of Mathematics, (2), vol. 28, No. 3, pp. 396-418; July, 1927.

Concerning the boundaries of domains of a continuous curve. Read Feb. 26, 1927. This Bulletin, vol. 33, No. 5, pp. 565-571; Sept.-Oct., 1927.

BELL, E. T. The general class number relations contained in Jacobi's theta formula. Read (San Francisco Section) April 5, 1924. Rendiconti del Circolo Matematico di Palermo, vol. 50, No. 3, pp. 368-374; Sept.-Dec., 1926.

- Reduction formulas for the number of representations of integers in certain quadratic forms. Read (San Francisco Section) Oct. 30, 1926. American Journal of Mathematics, vol. 49, No. 1, pp. 57-66; Jan., 1927.

Transformations of relations between numerical functions. Read (San Francisco Section) Oct. 25, 1924. Annali di Matematica, (4), vol. 4, Nos. 1-2, pp. 1-6; Nov., 1926-Feb., 1927.

A diophantine automorphism. Read (San Francisco Section) Oct. 30, 1926. This Bulletin, vol. 33, No. 1, pp. 71-80; Jan.-Feb., 1927.

- Successive generalizations in the theory of numbers. Read Sept. 8, 1926. American Mathematical Monthly, vol. 34, No. 2, pp. 55-75; Feb., 1927.

- Arithmetic of logic. Read (San Francisco Section) April 2, 1927. Transactions of this Society, vol. 29, No. 3, pp. 597-611; July, 1927.

- Cauchy's cyclotomic function and functional powers. Read (San Francisco Section), June 18, 1927. This Bulletin, vol. 33, No. 4, pp. 416-422; July-Aug., 1927.

Bennetr, A. A. New properties of an orthocentric system of triangles. Read Sept. 10, 1925. American Mathematical Monthly, vol. 33, No. 9, pp. 460-462; Nov., 1926.

Bennetr, T. Mapping by means of linear systems of curves invariant under Cremona involutions. Read Dec. 29, 1925. American Journal of Mathematics, vol. 48, No. 4, pp. 257-276; Oct., 1926.

Bernstein, A. B. The dual of a logical expression. Read (San Francisco Section) Oct. 30, 1926. This Bulletin, vol. 33, No. 3, pp. 309-311; May-June, 1927. 
Birkhoff, G. D. Stability and the equations of dynamics. Read Dec. 29 1926. American Journal of Mathematics, vol. 49, No. 1, pp. 1-38; Jan., 1927.

A mathematical critique of some physical theories. Read Dec. 30, 1926. This Bulletin, vol. 33, No. 2, pp. 165-181; March-April, 1927.

Brahana, H. R. Regular maps on an anchor ring. Read April 13, 1923. American Journal of Mathematics, vol. 48, No. 4, pp. 225-240; Oct., 1926.

- Regular maps and their groups. Read April 15, 1927. American Journal of Mathematics, vol. 49, No. 2, pp. 268-284; April, 1927.

Bray, H. E., and Evans, G. C. A class of functions harmonic within the sphere. Read April 28, 1923. American Journal of Mathematics, vol. 49, No. 2, pp. 153-180; April, 1927.

Brown, E. P. See Langer, R. E.

BRown, J. F. Orbits asymptotic to the straight line equilibrium points in the problem of three bodies in which the finite bodies are oblate spheroids. Read (San Francisco Section) June 12, 1926. Transactions of the Royal Society of Canada, (3), vol. 20, Section III, pp. $69-88 ; 1926$.

Buchanan, D. Isosceles-triangle orbits of the second genus. Read (San Francisco Section) June 12, 1926. Transactions of the Royal Society of Canada, (3), vol. 20, Section III, pp. 275-299; 1926.

- Periodic orbits of the second genus near the straight line equilibrium points in the problem of three bodies. Read (San Francisco Section) June 12, 1926. Proceedings of the Royal Society, (A), vol. 114, No. A768, pp. 490-516; April, 1927.

Cajori, F. Madame du Châtelet on fluxions. Read (San Francisco Section) Oct. 30, 1926. Mathematical Gazette, vol.13, No.185, p. 252; Dec., 1926. - Frederick the Great on mathematics and mathematicians. Read (San Francisco Section) Oct. 30, 1926. American Mathematical Monthly, vol. 34, No. 3, pp. 122-130; March, 1927.

The logarithms of Napier. Read (San Francisco Section) April 2, 1927. Science, new ser., vol. 65, No. 1692, p. 547; June 3, 1927.

Camp, C. C. A method for accelerating the convergence in the process of iteration. Read April 2, 1926. This Bulletin, vol. 33, No. 2, pp. 209220; March-April, 1927.

CAMpBEll, A. D. Three-parameter and four-parameter linear families of conics in the Galois fields of order $2^{n}$. Read Dec. 29, 1923. This Bulletin, vol. 33, No. 5, pp. 608-612; Sept.-Oct., 1927.

Campbell, J. W. A periodic solution for a certain problem in mechanics. Read Sept. 9, 1926. American Mathematical Monthly, vol. 34, No. 4, pp. 188-195; April, 1927.

Carmichael, R. D. Transformations leaving invariant certain partial differential equations of physics. Read Dec. 29, 1925. American Journal of Mathematics, vol. 49, No. 1, pp. 97-116; Jan., 1927.

Carpenter, A. F. Triads of ruled surfaces. Read (San Francisco Section) April 3, 1926. Transactions of this Society, vol. 29, No. 2, pp. 254-275; April, 1927. 
Chittenden, E. W. On the metrization problem and related problems in the theory of abstract sets. Read Sept. 8, 1926. This Bulletin, vol. 33, No. 1, pp. 13-34; Jan.-Feb., 1927.

Church, A. Alternatives to Zermelo's assumption. Read May 2, 1925. Transactions of this Society, vol. 29, No. 1, pp. 178-208; Jan., 1927.

Cleveland, C. M. Concerning points of a continuous curve that are not accessible from each other. Read May 1, 1926. Proceedings of the National Academy of Sciences, vol. 13, No. 4, pp. 275-276; May, 1927.

Copeland, A. H. Note on the Fourier development of continuous functions. Read April 16, 1927. This Bulleiin, vol. 33, No. 6, pp. 689-692; Nov.-Dec., 1927.

Cramlet, C. M. Applications of the determinant and permanent tensors to determinants of general class and allied tensor functions. Read (San Francisco Section) June 12, 1926. American Journal of Mathematics, vol. 49, No. 1, pp. 87-96; Jan., 1927.

DAvis, H. T. Derivation of the Fredholm theory from a differential equation of infinite order. Read April 19,1924. Annals of Mathematics, (2), vol. 28, No. 3, pp. 309-317; July, 1927.

Dickson, L. E. Quadratic forms which represent all integers. Read Dec. 31, 1926. Proceedings of the National Academy of Sciences, vol.12, No. 12, pp. 756-757; Dec., 1926.

Quaternary quadratic forms representing all integers. Read Dec. 31, 1926. American Journal of Mathematics, vol. 49, No. 1, pp. 39-56; Jan., 1927.

Integers represented by positive ternary quadratic forms. Read Dec. 31, 1926. This Bulletin, vol. 33, No. 1, pp. 63-70; Jan.-Feb.,1927.

- Singular case of pairs of bilinear, quadratic, or Hermitian forms. Read Dec. 26, 1924. Transactions of this Society, vol. 29, No. 2, pp. 239-253; April, 1927.

- Generalizations of Waring's theorem on fourth, sixth, and eighth powers. Read April 15, 1927. American Journal of Mathematics, vol. 49, No. 2, pp. 241-250; April, 1927.

- Extensions of Waring's theorem on nine cubes. Read April 15, 1927. American Mathematical Monthly, vol. 34, No. 4, pp. 177-183; April, 1927.

A generalization of Waring's theorem on nine cubes. Read April 15, 1927. This Bulletin, vol. 33, No. 3, pp. 299-300; May-June, 1927. Extensions of Waring's theorem on fourth powers. Read Dec. 31, 1926. This Bulletin, vol. 33, No. 3, pp. 319-327; May-June, 1927. Ternary quadratic forms and congruences. Read Dec. 31, 1926. Annals of Mathematics, (2), vol. 28, No. 3, pp. 333-341; July, 1927.

All positive integers are sums of values of a quadratic function of $x$. Read Sept. 9, 1927. This Bulletin, vol. 33, No. 6, pp. 713-720; Nov.Dec., 1927.

Dines, L. L. Note on certain associated systems of linear equalities and inequalities. Read (San Francisco Section) June 12, 1926. Annals of Mathematics, (2), vol. 28, No. 1, pp. 41-42; Dec., 1926. 
On sets of functions of a general variable. Read (San Francisco Section) June 12, 1926. Transactions of this Society, vol. 29, No. 2, pp. 463-470; April, 1927.

On positive solutions of a system of linear equations. Read (San Francisco Section) June 18, 1927. Annals of Mathematics, (2) vol. 28, No. 3, pp. 386-392; July, 1927.

On completely signed sets of functions. Read (San Francisco Section) June 18, 1927. Annals of Mathematics, (2), vol. 28, No. 3, pp. 393-395; July, 1927.

- Linear inequalities in general analysis. Read Sept. 8, 1927. This Bulletin, vol. 33, No. 6, pp. 695-700; Nov.-Dec., 1927.

DoDD, E. L. On certain averages in periodogram analysis. Read Dec. 29, 1925. Tôhoku Mathematical Journal, vol. 27, Nos. 3-4, pp. 271-276; Nov., 1926.

- The convergence of general means and the invariance of form of certain frequency functions. Read Dec. 31, 1926. American Journal of Mathematics, vol. 49, No. 2, pp. 215-220; April, 1927.

- The probability law for the intensity of a trial period, with data subject to the Gaussian law. Read May 7, 1927. This Bulletin, vol. 33. No. 6, pp. 681-684; Nov.-Dec., 1927.

Douglas, J. Extremals and transversality of the general calculus of variations problem of the first order in space. Read Feb. 26, 1927. Transactions of this Society, vol. 29, No. 2, pp. 401-420; April, 1927.

Емсн, A. On the mapping of the sextuples of the symmetric substitution group $G_{6}$ in a plane upon a quadric. Read Sept. 9, 1927. This Bulletin, vol. 33, No. 6, pp. 745-750; Nov.-Dec., 1927.

EtTLinger, H. J. On the inversion of the order of integration of a two fold iterated integral. Read Sept. 9, 1926. Annals of Mathematics, (2), vol. 28, No. 1, pp. 65-68; Dec., 1926.

— The kinetics of learning. Read Sept. 9, 1926. American Mathematical Monthly, vol. 33, No. 10, pp. 506-510; Dec., 1926.

On continuity in several variables. Read Oct. 30,1926 . This Bulletin, vol. 33, No. 1, pp. 37-38; Jan.-Feb., 1927.

Evans, G. C. The logarithmic potential. Discontinuous Dirichlet and Neumann problems. Read Sept. 9, 1926, and (Southwestern Section) Nov. 27, 1926. American Mathematical Society Colloquium Series, New York, 1927.

- See Bray, H. E.

Fite, W. B. Periodic solutions of linear differential equations. Read Jan. 1, 1926. Annals of Mathematics, (2), vol. 28, No. 1, pp. 59-64; Dec., 1926.

ForT, T. An elementary proof by mathematical induction of the equivalence of the Cesàro and Hölder sum formulas. Read Dec. 29, 1926. This Bulletin, vol. 33, No. 3, pp. 301-304; May-June, 1927.

Foster, M. C. Ruled surfaces referred to the trihedral of a directrix. Read May 1, 1926. American Mathematical Monthly, vol. 34, No. 6, pp. 303-307; June-July, 1927.

Congruences of lines of special orientation relative to a surface of reference. Read Dec. 28, 1926. This Bulletin, vol. 33, No. 6, pp. 750759; Nov.-Dec., 1927. 
FrankLin, P. The Simson lines of a triangle, the three-cusped hypocycloid and the Morley triangles. Read Oct. 30,1926. Journal of Mathematics and Physics of the Massachusetts Institute of Technology, vol. 6, No.1, pp. 50-61; Nov., 1926.

A geometric characterization of equipotential and stream lines. Read Jan. 2, 1926. Journal of Mathematics and Physics of the Massachusetts Institute of Technology, vol. 6, No.4, pp. 191-208; June, 1927. A theorem of Frobenius on quadratic forms. Read Dec. 29, 1926. This Bulletin, vol. 33, No. 4, pp. 447-452; July-Aug., 1927.

- Analytic functions with assigned values. Read Feb. 26, 1927. This Bulletin, vol. 33, No. 4, pp. 461-466; July-Aug., 1927.

Garver, R. Transformations of one principal equation into another. Read Feb. 26, 1927. Annals of Mathematics, (2), vol. 28, No. 2, pp. 112-116; April, 1927.

- A type of function with $k$ discontinuities. Read May 7, 1927. American Mathematical Monthly, vol. 34, No. 7, pp. 362-363; Aug.-Sept., 1927.

The binomial quartic as a normal form. Read Oct. 29, 1927 This Bulletin, vol. 33, No. 6, pp. 677-680; Nov.-Dec., 1927.

Gehman, H. M. Some relations between a continuous curve and its subsets. Read Feb. 27, 1926, and (San Francisco Section) June 12, 1926. Annals of Mathematics, (2), vol. 28, No. 2, pp. 103-111; April, 1927.

- Irreducible continuous curves. Read Feb. 27, 1926. American Journal of Mathematics, vol. 49, No. 2, pp. 189-196; April, 1927.

- Concerning acyclic continuous curves. Read Oct. 31, 1925. Transactions of this Society, vol. 29, No. 3, pp. 553-568; July, 1927.

GLenN, O. E. Recent progress of investigations by symbolic methods of bi-ternary quantics. Read Sept. 9, 1926. Proceedings of the National Academy of Sciences, vol. 13, No. 5, pp. 276-280; May, 1927.

- A theory of integers, in relation to the iteration of algebraic functions. Read Dec. 29, 1924, and Feb. 26, 1927. Annals of Mathematics, (2), vol. 28, No. 3, pp. 368-378; July, 1927.

GoFf, J. A. Transformations leaving invariant the heat equation of physics. Read Dec. 29, 1925. American Journal of Mathematics, vol. 49, No. 1, pp. 117-122; Jan., 1927.

Gourin, E. See Ritr, J. F.

Graves, L. M. Riemann integration and Taylor's theorem in general analysis. Read Sept. 10, 1925. Transactions of this Society, vol. 29, No. 1, pp. 163-177; Jan., 1927.

On the existence of the absolute minimum in space problems of the calculus of variations. Read Oct. 30,1926. Annals of Mathematics, (2), vol. 28, No. 2, pp. 153-170; April, 1927.

- Implicit functions and differential equations in general analysis. Read May 1, 1926. Transactions of this Society, vol. 29, No. 3, pp. 514-552; July, 1927.

See Hildebrandt, T. H. 
Gronwall, T. H. The longitudinal vibrations of a liquid contained in a tube with elastic walls. Read Feb. 26, 1927. Physical Review, (2), vol. 30, No. 1, pp. 71-83; July, 1927.

- On the existence and properties of the solutions of a certain differential equation of the second order. Read Jan. 2, 1926, and Feb. 26, 1927. Annals of Mathematics, (2), vol. 28, No. 3, pp. 355-364; July, 1927.

Grove, V. G. A general theory of nets on a surface. Read April 10, 1925. Transactions of this Society, vol. 29, No. 4. pp. 801-814; Oct., 1927.

Hazlett, O. C. The arithmetic of a general algebra. Read Dec. 29, 1925. Annals of Mathematics, (2), vol. 28, No. 1, pp. 92-102; Dec., 1926.

- Notes on formal modular protomorphs. Read Sept. 9, 1926. American Journal of Mathematics, vol. 49, No. 2, pp. 181-188; April, 1927.

Herzfeld, K. F. See Murnaghan, F. D.

Hildebrandt, T. H., and Graves, L. M. Implicit functions and their differentials in general analysis. Read March 25, 1921, and Dec. 29, 1924. Transactions of this Society, vol. 29, No. 1, pp. 127-153; Jan., 1927.

Hille, E. On Laguerre's series. Three notes. Read Feb. 27, 1926. Proceedings of the National Academy of Sciences, vol. 12, No. 4, pp. 261265; 265-269, and No. 5, pp. 348-352; April and May, 1926.

Hofmann, L. Über einige spezielle Strahlenkongruenzen, die mit analytischen Funktionen zusammenhängen. Read April 16, 1927. Dissertation, University of Zurich. Zurich, 1927. $68 \mathrm{pp}$.

Hollcroft, T. R. Singularities of the Hessian. Read Oct. 30, 1926. This Bulletin, vol. 33, No. 1, pp. 90-96; Jan.-Feb., 1927.

- On the reality of singularities of plane curves. Read Sept. 10, 1925. Mathematische Annalen, vol. 97, Nos. 4-5, pp. 775-787; June, 1927.

Hotelling, H. An application of analysis situs to statistics. Read (San Francisco Section) Oct. 30, 1926. This Bulletin, vol. 33, No. 4, pp. 467-476; July-Aug., 1927.

Huber, C. M. On complete systems of irrational invariants of associated point sets. Read Oct. 30, 1926. American Journal of Mathematics, vol. 49, No. 2, pp. 251-267; April, 1927.

Huntington, E. V. Sets of independent postulates for the arithmetic mean, the geometric mean, the harmonic mean, and the rootmean-square. Read Dec. 29, 1925. Transactions of this Society, vol. 29, No. 1, pp. 1-22; Jan., 1927.

Hurwitz, W. A. Some properties of methods of evaluation of divergent sequences. Read Dec. 28, 1920. Proceedings of the London Mathematical Society, (2), vol. 26, Nos. 3-4, pp. 231-240, 241-248; March and May, 1927.

Ingraham, M. H. Note on the extensions of groups to obtain $n$-th roots. Read Dec. 29, 1925. Annals of Mathematics, (2), vol. 28, No. 1, pp. 53-58; Dec., 1926.

Jensen, C. M. Some problems in the theory of interpolation by SturmLiouville functions. Read April 19, 1924. Transactions of this Society, vol. 29, No. 1, pp. 54-79; Jan., 1927. 
KLINE, J. R. A condition that every subcontinu of a continuous curve be a continuous curve. Read Dec. 29, 1925. Fundamenta Mathematicae, vol. 10, pp. 298-301; 1927.

Koopman, B. O. On rejection to infinity and exterior motion in the restricted problem of three bodies. Read Jan. 2, 1926. Transactions of this Society, vol. 29, No. 2, pp. 287-331; April, 1927.

On analytic solutions of differential equations in the neighborhood of non-analytic singular points. Read Oct. 30, 1926. This Bulletin, vol. 33, No. 3, pp. 341-351; May-June, 1927.

LANe, E. P. The contact of a cubic surface with an analytic surface. Read Sept. 9, 1926. Transactions of this Society, vol. 29, No. 3, pp. 471-480; July, 1927.

LANGER, R. E. Three theorems on closure of biorthogonal systems of functions. Read Dec. 28, 1926. This Bulletin, vol. 33, No. 1, pp. 97105; Jan.-Feb., 1927.

LANGER, R. E., and Brown, E. P. On a class of integral equations with discontinuous kernels. Read Dec. 28, 1926. Transactions of this Society, vol. 29, No. 4, pp. 683-715; Oct., 1927.

LANGFord, C. H. Some theorems on deducibility. Read Feb. 27, 1926. Annals of Mathematics, (2), vol. 28, No. 1, pp. 16-40; Dec., 1926.

- On a type of completeness characterizing the general laws for separation of point-pairs. Read Jan. 1, 1926. Transactions of this Society, vol. 29, No. 1, pp. 96-110; Jan., 1927.

On inductive relations. Read May 7, 1927. This Bulletin, vol. 33, No. 5, pp. 599-607; Sept.-Oct., 1927.

An analysis of some general propositions. Read Sept. 9, 1927. This Bulletin, vol. 33, No. 6, pp. 666-672; Nov.-Dec., 1927.

Lefschetz, S. Transformations of manifolds with a boundary. Read Oct. 30, 1926. Proceedings of the National Academy of Sciences, vol. 12, No. 12, pp. 737-739; Dec., 1926.

- Manifolds with a boundary and their transformations. Read Oct. 30, 1926. Transactions of this Society, vol. 29, No. 2, pp. 429-462; April, 1927.

Correspondences between algebraic curves. Read April 15, 1927. Annals of Mathematics, (2), vol. 28, No. 3, pp. 342-354; July, 1927.

Lehmer, D. H. Tests for primality by the converse of Fermat's theorem. Read (San Francisco Section) April 2, 1927. This Bulletin, vol. 33, No. 3, pp. 327-340; May-June, 1927.

Lehmer, D. N. A theorem on factorization. Read (San Francisco Section) Oct. 30, 1926. This Bulletin, vol. 33, No. 1, pp. 35-36; Jan.-Feb., 1927.

LEHR, M. The plane quintic with five cusps. Read Dec. 29, 1924. American Journal of Mathematics, vol. 49, No. 2, pp. 197-214; April, 1927.

Levy, H. Congruences of curves in the geometry of paths. Read May 1, 1926. Rendiconti del Circolo Matematico di Palermo, vol. 51, No. 2, pp. 304-311; May-August, 1927.

Linfield, B. Z. Espace discret paramétrique et non paramétrique. Read Oct. 28 and Dec. 27, 1922. Dissertation, University of Strasbourg. Paris, Gauthier-Villars, 1925. 121 pp. 
McDonald, J. H. The differential equation of the elliptic cylinder. Read (San Francisco Section) April 4, 1925. Transactions of this Society, vol. 29, No. 4, pp. 647-682; Oct., 1927.

Manning, W. A. On simply transitive primitive groups. Read (San Francisco Section) Oct. 30, 1926, and Dec. 31, 1926. Proceedings of the National Academy of Sciences, vol. 12, No. 12, pp. 761-767; Dec., 1926. Simply transitive primitive groups. Read (San Francisco Section) Oct. 30, 1926, and Dec. 31, 1926. Transactions of this Society, vol. 29, No. 4, pp. 815-825; Oct., 1927.

March, H. W. The Heaviside operational calculus. Read Dec. 31, 1926. This Bulletin, vol. 33, No. 3, pp. 311-318; May-June, 1927.

Merriman, G. M. On certain sufficient conditions for the convergence and Cesàro summability of the allied series of a double Fourier series. Read Sept. 9, 1927. This Bulletin, vol. 33, No. 5, pp. 576-583; Sept.Oct., 1927.

Michal, A. D. Functionals of $r$-dimensional manifolds admitting continuous groups of point transformations. Read March 1, 1924, and Jan. 1, 1926. Transactions of this Society, vol. 29, No. 3, pp. 612-646; July, 1927.

Michal, A. D., and Thomas, T. Y. Differential invariants of affinely connected manifolds. Read Sept. 8, 1926. Annals of Mathematics, (2), vol. 28, No. 2, pp. 196-236; April, 1927.

Miller, G. A. Subgroups of index $p^{2}$ contained in a group of order $p^{m}$. Read Sept. 9, 1926. American Journal of Mathematics, vol. 48, No. 4, pp. 253-256; Oct., 1926.

- Postulates in the history of science. Read Sept. 9, 1926. Proceedings of the National Academy of Sciences, vol.12, No.12, pp. 761-767; Dec., 1926.

- Substitutions which transform a regular group into its conjoint. Read Sept. 9, 1927. This Bulletin, vol.33, No.6, pp. 701-706; Nov.Dec., 1927.

Miller, N. On related maxima and minima. Read Sept. 9, 1926. Annals of Mathematics, (2), vol. 28, No. 2, pp. 117-126; April, 1927.

Moore, C. L. E. Note on surfaces in a non-Riemannian space. Read Sept. 8, 1926. Journal of Mathematics and Physics of the Massachusetts Institute of Technology, vol. 6, No. 1, pp. 39-49; Nov., 1926.

Moore, C. N. On convergence factors in multiple series. Read Dec. 28, 1923, and Sept. 11, 1925. Transactions of this Society, vol. 29, No. 1, pp. 227-238; Jan., 1927.

Moore, R. L. Concerning paths which do not separate a given continuous curve. Read Oct. 30,1926. Proceedings of the National Academy of Sciences, vol. 12, No. 12, pp. 745-753; Dec., 1926.

Moritz, R. E. A modification of Glaisher's proof of Stirling's theorem. Read (San Francisco Section) June 18, 1927. Messenger of Mathematics, vol. 56, No. 12, pp. 181-184; April, 1927.

Mullings, M. E. The rotational derivative and some applications. Read Sept. 9, 1926. American Mathematical Monthly, vol. 34, No. 5, pp. 241-247; May, 1927. 
Murnaghan, F. D. Note sur l'orthopole. Read Sept. 7, 1923. Mathesis, vol. 41, No. 1, pp. 24-28; Jan., 1927.

- The Cauchy-Heaviside expansion problem and the BoltzmannHopkinson principle of superposition. Read Sept. 9, 1926. This Bulletin, vol. 33, No. 1, pp. 81-89; Jan.-Feb., 1927.

- The duty of exposition with special reference to the CauchyHeaviside expansion theorem. Read Dec. 30, 1926. American Mathematical Monthly, vol. 34, No. 5, pp. 234-241; May, 1927.

Murnaghan, F. D., and Herzfeld, K. F. Two remarks on the wavetheory of mechanics. Read May 7, 1927. Proceedings of the National Academy of Sciences, vol. 13, No. 5, pp. 330-336; May, 1927.

Murray, F. H. Generalization of certain theorems of Bohl, [Second paper]. Read Sept. 10, 1925. American Journal of Mathematics, vol. 49, No. 1, pp. 67-86; Jan., 1927.

Musselman, J. R. On the linear correlation ratio in the case of certain symmetrical frequency distributions. Read Dec. 28, 1926. Biometrika, vol. 18, Nos. 1-2, pp. 228-231; July, 1926.

Nassau, J. J. Some extensions of the generalized Kronecker symbol. Read April 3, 1926. Annals of Mathematics, (2), vol. 27, No. 4, pp. 465-470; Sept., 1926.

Niemytzki, V. W. On the "third axiom of metric space." Read Sept. 9, 1926. Transactions of this Society, vol. 29, No.3, pp. 507-513; July, 1927.

Olson, H. L. Linear congruences in a general arithmetic. Read Sept. 9, 1926. Annals of Mathematics, (2), vol. 28, No. 2, pp. 237-239; April, 1927.

Pierpont, J. Classification of quadrics in hyperbolic space. Read Oct. 30, 1926. American Journal of Mathematics, vol. 49, No. 1, pp. 143151; Jan., 1927.

On a generalization of the secular equation. Read Dec. 29, 1926. This Bulletin, vol. 33, No. 3, pp. 294-296; May-June, 1927.

Raudenbush, H. W. On Hilbert's thirteenth Paris problem. Read Feb. 26, 1927. This Bulletin, vol. 33, No. 4, pp. 433-434; July-Aug., 1927.

Raynor, G. E. Generalization of the Beltrami equations to $n$-space. Read Sept. 9, 1926. This Bulletin, vol. 33, No. 4, pp. 435-439; July-Aug., 1927.

Reilly, J. F. Interpolation formulas dependent upon the underlying function. Read April 10, 1925. American Mathematical Monthly, vol. 34, No. 6, pp. 296-299; June-July, 1927.

Reynolds, C. N. On the problem of coloring maps in four colors. Read Feb. 28, 1925. Annals of Mathematics, (2), vol. 28, No. 1, pp. 1-15; Dec., 1926.

Rice, L. H. Compounds of Cayley products of determinants of higher class. Read Oct. 30, 1926. Journal of Mathematics and Physics of the Massachusetts Institute of Technology, vol. 6, No. 1, pp. 33-38; Nov., 1926. 
RIDER, P. R. The devil's curve and abelian integrals. Read April 16, 1927. American Mathematical Monthly, vol. 34, No. 4, pp. 199-203; April, 1927.

A figuratrix for double integrals. Read April 2 and Sept. 9, 1926. Transactions of this Society, vol. 29, No. 2, pp. 421-428; April, 1927.

The analysis of a U-shaped frequency distribution. Read Dec. 29, 1925. Journal of the American Statistical Association, new ser., vol. 22, No. 158, pp. 202-208; June, 1927.

Ritr, J. F. Simplification de la méthode de Liouville dans la théorie des fonctions élémentaires. Read Oct. 30, 1926. Abstract in Comptes Rendus de l'Académie des Sciences, vol. 183, No. 5, pp. 331-332; Aug. 2, 1926.

- On the integration in finite terms of linear differential equations of the second order. Read Oct. 25, 1924. This Bulletin, vol. 33, No. 1, pp. 51-57; Jan.-Feb., 1927.

- Real functions with algebraic addition theorems. Read Feb. 27, 1926. Transactions of this Society, vol. 29, No. 2, pp. 361-368; April, 1927.

- Meromorphic functions with addition or multiplication theorems. Read Feb. 27, 1926. Transactions of this Society, vol. 29, No. 2, pp. 341-360; April, 1927.

- A factorization theory for functions $\sum_{i=1}^{n} a_{n} e^{\alpha_{n} x}$. Read Oct. 30, 1926. Transactions of this Society, vol. 29, No. 3, pp. 584-596; July, 1927.

RitT, J. F., and Gourin, E. An assemblage-theoretic proof of the existence of transcendentally transcendental functions. Read Dec. 29, 1926. This Bulletin, vol. 33, No. 2, pp. 182-184; March-April, 1927.

Robertson, H. P. Dynamical space-times which contain a conformal euclidean 3-space. Read (San Francisco Section) June 19, 1925. Transactions of this Society, vol. 29, No. 3, pp. 481-496; July, 1927.

Roos, C. F. Dynamical economics. Read Dec. 31, 1926. Proceedings of the National Academy of Sciences, vol. 13, No. 3, pp. 145-150; March, 1927.

- A dynamical theory of economic equilibrium. Read Dec. 31, 1926. Proceedings of the National Academy of Sciences, vol. 13, No. 5, pp. 280-285; May, 1927.

Rosebrugh, T. R. A general theorem on quantic determinants. Read Feb. 26, 1927. This Bulletin, vol. 33, No. 5, pp. 583-590; Sept.-Oct., 1927.

Sнонат, J. Sur quelques applications des polynomes de Tchebycheff à plusieurs variables. Read April 2, 1926. Abstract in Comptes Rendus de l'Académie des Sciences, vol. 183, No. 8, pp. 442-444; Aug. 23, 1926.

- Sur les expressions asymptotiques des polynomes de Tchebycheff et de leurs dérivées. Read Dec. 31, 1926. Abstract in Comptes Rendus de l'Académie des Sciences, vol. 183, No. 17, pp. 697-699; Oct. 26, 1926. 
On a general formula in the theory of Tchebycheff polynomials and its applications. Read Sept. 11, 1925. Transactions of this Society, vol. 29, No. 3, pp. 569-583; July, 1927.

A simple method for normalizing Tchebycheff polynomials and evaluating the elements of the allied continued fractions. Read April 16, 1927. This Bulletin, vol. 33, No. 4, pp. 427-432; July-Aug., 1927.

SNyder, V. On a problem in closure. Read Sept. 8, 1926. This Bulletin, vol. 33, No. 1, pp. 39-43; Jan.-Feb., 1927.

STARK, M. E. A self-adjoint boundary value problem associated with a problem of the calculus of variations. Read Jan. 2, 1926. Dissertation, University of Chicago. Abstract printed by the University.

Starke, E. P. Certain uniform functions of rational functions. Read May 1, 1926. Transactions of this Society, vol. 29, No. 2, pp. 276-286; April, 1927.

Stone, M. H. Irregular differential systems of order two and the related expansion problems. Read Dec. 30,1924. Transactions of this Society, vol. 29, No. 1, pp. 23-53; Jan., 1927.

- Expansions in Bessel functions. Read Oct. 31, 1925. Annals of Mathematics, (2), vol. 28, No. 3, pp. 271-290; July, 1927.

- The expansion problems associated with regular differential systems of the second order. Read Oct. 30,1927. Transactions of this Society, vol. 29, No. 4, pp. 826-844; Oct., 1927.

Stouffer, E. B. Singular ruled surfaces in space of five dimensions. Read Dec. 28, 1918. Transactions of this Society, vol. 29, No. 1, pp. 80-95; Jan., 1927.

Struik, D. J. On the geometry of linear displacement. Read Feb. 26, 1927. This Bulletin, vol. 33, No. 5, pp. 523-564; Sept.-Oct., 1927.

- See Wiener, N.

TAmarkin, J. D. On Fredholm's integral equations, whose kernels are analytic in a parameter. Read Sept. 9, 1926. Annals of Mathematics, (2), vol. 28, No. 2, pp. 127-152; April, 1927.

- The notion of Green's function in the theory of integro-differential equations. Read Jan. 1, 1926. Transactions of this Society, vol. 29, No. 4, pp. 755-800; Oct., 1927.

Thomas, J. M. Note on a differential equation. Read Sept. 9, 1926. Annals of Mathematics, (2), vol. 28, No. 2, pp. 240-244; April, 1927.

- On systems of total differential equations. Read Feb. 26, 1927. Annals of Mathematics, (2), vol. 28, No. 3, pp. 379-385; July, 1927.

Thomas, T. Y. The identities of affinely connected manifolds. Read Oct. 31, 1925. Mathematische Zeitschrift, vol. 25, No. 4, pp. 714-722; Dec., 1926.

A projective theory of affinely connected manifolds. Read Sept. 10, 1925. Mathematische Zeitschrift, vol. 25, No. 4, pp. 723-733; Dec., 1926.

- See Michal, A. D. 
Trjitzinsky, W. J. Zeros of a function and of its derivative. Read (San Francisco Section) June 18, 1927. This Bulletin, vol. 33, No. 6, pp. 693-695; Nov.-Dec., 1927.

De la Vallée Poussin, C. On the approximation of functions of a real variable and on quasi-analytic functions. Read Dec. 30, 1924. Rice Institute Pamphlet, vol. 12, No. 2, pp. 105-172; April, 1925.

VANDIVER, H. S. Summary of results and proofs concerning Fermat's last theorem (second note). Read Dec. 29, 1923, and May 1, 1926. Proceedings of the National Academy of Sciences, vol. 12, No. 12, pp. 767-772; Dec., 1926.

- Application of the theory of relative cyclic fields to both cases of Fermat's last theorem (second paper). Read Jan. 1, 1926. Transactions of this Society, vol. 29, No. 1, pp. 154-162; Jan., 1927.

- On the least multiple of an integer expressible as a definite quadratic form. Read May 1, 1926. American Mathematical Monthly, vol. 34, No. 2, pp. 86-88; Feb., 1927.

- Application of algebraic number theory to congruences involving binomial coefficients. Read Dec. 29, 1926. Annals of Mathematics, (2), vol. 28, No. 3, pp. 330-332; July, 1927.

Vinogradov, I. M. On a general theorem concerning the distribution of the residues and non-residues of powers. Read Sept. 9, 1926. Transactions of this Society, vol. 29, No. 1, pp. 209-217; Jan., 1927.

- On the bound of the least non-residue of $n$th powers. Read Sept. 9, 1926. Transactions of this Society, vol. 29, No. 1, pp. 218-226; Jan., 1927.

WAHLin, G. E. A quadratic algebra and its application to a problem in Diophantine analysis. Read April 10, 1925. This Bulletin, vol. 33, No. 2, pp. 221-231; March-April, 1927.

WALSH, J. L. Sur la position des racines des fonctions entières de genre zéro et un. Read Oct. 31, 1925. Abstract in Comptes Rendus de l'Académie des Sciences, vol. 180, No. 26, pp. 2009-2011; June 29, 1925. Über den Grad der Approximation einer analytischen Funktion. Read Sept. 9, 1926. Sitzungsberichte der mathematisch-naturwissenschaftlichen Abteilung der Bayerischen Akademie der Wissenschaften, 1926, Heft II, pp. 223-229; May-July, 1926.

Über die Entwicklung einer analytischen Funktion nach Polynomen. Read Oct. 31, 1925. Mathematische Annalen, vol. 96, Nos. 3-4, pp. 430-436; Oct., 1926.

Über die Entwicklung einer Funktion einer komplexen Veränderlichen nach Polynomen. Read Feb. 27, 1926. Mathematische Annalen, vol. 96, Nos. 3-4, pp. 437-450; Oct., 1926.

- On the expansion of harmonic functions in terms of harmonic polynomials. Read Dec. 29, 1926. Proceedings of the National Academy of Sciences, vol. 13, No. 4, pp. 175-180; April, 1927.

On the degree of approximation to a harmonic function. Read Sept. 9,1927. This Bulletin, vol.33, No. 5, pp.591-598; Sept.-Oct., 1927. 
WARD, L. E. Functions expansible in series. Read April 2, 1926. This Bulletin, vol. 33, No. 2, pp. 232-234; March-April, 1927.

Some third-order irregular boundary value problems. Read April 16, 1927. Transactions of this Society, vol. 29, No. 4, pp. 716-745; Oct., 1927.

Weaver, J. H. Invariants of a poristic system of triangles. Read Sept. 8, 1926. This Bulletin, vol. 33, No. 2, pp. 235-240; March-April, 1927.

WEjDA, F. M. On the correlation between two functions. Read Jan. 1, 1926. American Mathematical Monthly, vol. 33, No. 9, pp. 440-444; Nov., 1926.

WeIsner, L. A theorem concerning direct products. Read Oct. 30, 1926. This Bulletin, vol. 33, No. 1, pp. 44-45; Jan.-Feb., 1927.

The functional equation defining diophantine automorphisms. Read May 7, 1927. This Bulletin, vol. 33, No. 6, pp. 707-712; Nov.-Dec., 1927.

Whyвurn, G. T. Concerning certain types of continuous curves. Read Sept. 9, 1926. Proceedings of the National Academy of Sciences, vol. 12, No. 12, pp. 761-767; Dec., 1926.

- Cyclically connected continuous curves. Read Dec. 31, 1926. Proceedings of the National Academy of Sciences, vol. 13, No. 2, pp. 31-38; Feb., 1927.

The most general closed point set over which continuous function may be defined by certain properties. Read Sept. 9, 1926. This Bulletin, vol. 33, No. 2, pp. 185-188; March-April, 1927.

Concerning continua in the plane. Read Dec. 29, 1925, and Feb. 27, April 2, May 1, and (San Francisco Section) June 12, 1926. Transactions of this Society, vol. 29, No. 2, pp. 369-400; April, 1927.

- Some properties of continuous curves. Read Dec. 31, 1926. This Bulletin, vol. 33, No. 3, pp. 305-308; May-June, 1927.

Concerning point sets which can be made connected by the addition of a simple continuous arc. Read April 2,1926. Transactions of this Society, vol. 29, No. 4, pp. 746-754; Oct., 1927.

Concerning the disconnection of continua by the omission of pairs of their points. Read Feb. 27, 1926. Fundamenta Mathematicae, vol. 10, pp. 180-185; 1927.

Concerning connected and regular point sets. Read (San Francisco Section) June 18, 1927. This Bulletin, vol. 33, No. 6, pp. 685-689; Nov.-Dec., 1927.

Whyburn, W. M. On Green's function for systems of differential equations. Read Oct. 30, 1926. Annals of Mathematics, (2), vol. 28, No. 3, pp. 291-300; July, 1927.

On the polynomial convergents of power series. Read April 16, 1927. This Bulletin, vol. 33, No. 6, pp. 673-676; Nov.-Dec., 1927. 
Widder, D. V. Note on a generalization of Taylor's series. Read Dec. 29, 1926. Proceedings of the National Academy of Sciences, vol. 13, No. 3, pp. 156-160; March, 1927.

On the interpolatory properties of a linear combination of continuous functions. Read Dec. 29, 1926. American Journal of Mathematics, vol. 49, No. 2, pp. 221-234; April, 1927.

- Note on Tchebycheff approximation. Read Dec. 29, 1926. American Journal of Mathematics, vol. 49, No. 2, pp. 235-240; April, 1927.

- Un théorème sur les séries de Dirichlet. Read April 16, 1927. Comptes Rendus de l'Académie des Sciences, vol. 184, No. 18, pp. 138-140; May 2, 1927.

WiEner, N. On the closure of certain assemblages of trigonometrical functions. Read Feb. 26, 1927. Proceedings of the National Academy of Sciences, vol. 13, No. 2, pp. 27-29; Feb., 1927.

- Laplacians and continuous linear functionals. Read Feb. 26, 1927. Acta Litterarum ac Scientiarum Regiae Universitatis Hungaricae Francisco-Josephinae, Sectio Scientiarum Mathematicarum, vol. 3, No. 1, pp. 7-16; Feb., 1927.

- Une méthode nouvelle pour la démonstration de théorèmes de M. Tauber. Read Feb. 36, 1927. Comptes Rendus de l'Académie des Sciences, vol. 184, No. 13, pp. 793-795; March 28, 1927.

- A new definition of almost periodic functions. Read Feb. 26, 1927. Annals of Mathematics, (2), vol. 28, No. 3, pp. 365-367; July, 1927.

Wiener, N., and Struik, D. J. Quantum theory and gravitational relativity. Read May 7, 1927. Nature, vol. 119, No. 3006, pp. 853-854; June 11, 1927.

—- Sur la théorie relativiste des quanta. Read May 7, 1927. Comptes Rendus de l'Académie des Sciences, vol. 185, No. 3, pp. 184-185; July 18, 1927 .

WILDER, C. E. Reduction of the ordinary linear differential equation of the $n$th order whose coefficients are certain polynomials in a parameter to a system of $n$ first-order equations which are linear in the parameter. Read Sept. 9, 1926. Transactions of this Society, vol. 29, No. 3, pp. 497-506; July, 1927.

Wilder, R. L. A connected and regular point set which has no subcontinuum. Read April 2, 1926. Transactions of this Society, vol. 29, No. 2, pp. 332-340; April, 1927.

A point set which has no true quasi-components, and which becomes connected upon the addition of a single point. Read Feb. 26, 1927. This Bulletin, vol. 33, No. 4, pp. 423-427; July-Aug., 1927.

The non-existence of a certain type of regular point set. Read Dec. 29, 1926. This Bulletin, vol. 33, No. 4, pp. 439-446; July-Aug., 1927.

Williams, H. B. Mathematics and the biological sciences. Read Dec. 28, 1926. This Bulletin, vol. 33, No. 3, pp. 273-293; May-June, 1927. 
WiLson, N. R. Integers and basis of a number field. Read Dec. 29, 1925. Transactions of this Society, vol. 29, No. 1, pp. 111-126; Jan., 1927.

Wirson, W. A. On the separation of a plane by irreducible continua. Read Oct. 30, 1926. This Bulletin, vol. 33, No. 6, pp. 733-744; Nov.Dec., 1927.

Wong, B. C. Sextic surfaces with a double septimic curve. Read (San Francisco Section) April 2, 1927. Annals of Mathematics, (2), vol. 28, No. 3, pp. 251-262; July, 1927.

YounG, J. W. On the partitions of a group and the resulting classification. Read Sept. 9, 1926. This Bulletin, vol. 33, No. 4, pp. 453-461; JulyAug., 1927.

Zeldin, S. D. Contact transformations in intrinsic geometry. Read Dec. 28, 1926. Journal of Mathematics and Physics of the Massachusetts Institute of Technology, vol. 6, No. 4, pp. 223-239; June, 1927. 